\title{
AMBIENT AIR PROTECTION IN THE SYSTEM OF PUBLIC HEALTH AND BIOLOGICAL SECURITY LEGAL PROVISION
}

DOI: 10.36740/WLek202109132

\author{
Vitalii Pashkov ${ }^{1,2}$, Maryna V. Trotska ${ }^{2}$, Liudmyla M. Nikolenko ${ }^{3}$ \\ 'POLTAVA LAW INSTITUTE OF YAROSLAV MUDRYI NATIONAL LAW UNIVERSITY, POLTAVA, UKRAINE \\ ¿LABORATORY FOR THE STUDY OF NATIONAL SECURITY PROBLEMS IN THE FIELD OF PUBLIC HEALTH OF ACADEMICIAN STASHIS SCIENTIFIC RESEARCH \\ INSTITUTE FOR THE STUDY OF CRIME PROBLEMS, KHARKIV, UKRAINE \\ ${ }^{3}$ DONETSK STATE UNIVERSITY OF INTERNAL AFFAIRS, MARIUPOL, UKRAINE
}

\begin{abstract}
The article examines the legal and regulatory basis for ambient air protection as an essential element of the environment that affects biological security the health and livelihoods of the population. Proper legal regulation of ambient air protection is important in the implementation of various measures aimed at preserving its quality and, accordingly, preventing possible adverse effects on human health. Ambient air protection is a certain activity directed at reducing the number of pollutants that get into the air by one means or another. In the process of environmental protection in general and ambient air protection in particular, the legal basis and case law are important components that aimed to minimize the occurrence of potential hazards that could threaten the health and lives of the population, and in case of such situations, identify the causes of their occurrence and respond to them proportionally.
\end{abstract}

KEY WORDS: in the biological security system, biosecurity system, air, ambient air, ambient air protection, health, public health

Wiad Lek. 2021;74(9 p.l):2207-2212

\section{INTRODUCTION}

Ambient air in the biological security system is an integral part of the natural environment that directly or indirectly affects life and health of the population. Air pollutants can lead to health problems either directly when they penetrate the organism or indirectly by the modification of the environment. Pollutants enter the organism through three different mechanisms. 1) Inhalation: man breathes $\sim 15 \mathrm{~m} 3$ of air, including pollutants every day. 2) Ingestion: some air pollutants can deposit onto soil or surface water, where they are taken up by plants and ingested by animals, and are eventually introduced into the food chain. 3) Skin contact: this type of contact is less frequent, except in case of accidental pollution or armed conflicts [1, p. 116-117]. Human activity in any of its manifestations depends on various factors including the state of the environment in general and natural resources in particular, with ambient air occupying its appropriate place among others. Air pollution is a major problem of recent decades, which has a serious toxicological impact on human health and the environment [2]. Air pollution, particularly in urban areas, constitutes a public health concern, as it has a harmful effect on the health, survival, and activities of humans and other living organisms $[1$, p. 109]. The burden of atmospheric pollution must be reduced to protect human health by an adequate safety margin [3]. The importance of researching the designated issue is beyond doubt since the legal regulation of the outlined area contributes to ensuring the proper quality of air and preventing possible negative impacts on life and health of people. In turn, the need to ensure the proper state of the environment, both in general and its individual components in particular, has been repeatedly noted at the general theoretical level [4-13].

According to dictionary sources, the air is a predominantly mechanical mixture of a variety of individual gases forming the earth's enveloping atmosphere [14]. Air is the invisible mixture of gases that surrounds the Earth. Air contains important substances, such as oxygen and nitrogen, that most species need to survive [15]. "Ambient air" - the air occurring at a particular time and place outside of structures. Often used interchangeably with «outdoor air» [16]. "Ambient air" means the air that is breathed by the general public in the community [17]. Whereas, legal regulations specify that 'ambient air' shall mean outdoor air in the troposphere, excluding workplaces as defined by Directive 89/654/EEC where provisions concerning health and safety at work apply and to which members of the public do not have regular access (Article 2, para.1, subparagraph 1, of the Directive 2008/50/EC of the European Parliament and of the Council of 21 May 2008 on ambient air quality and cleaner air for Europe [18]). Ambient air is outdoor air in the troposphere, excluding air in working environment (part 2 paragraph 3 Division 1 General Provisions Atmospheric Air Protection Act [19]. Thus, ambient air is defined as the set of gases located outside the accordingly defined places. 
In considering the importance of natural resources in general and the air in particular for public health and in the biological security system in general, we should state first that public health is defined as the discipline in health science that, at the level of the community or the public, aims at promoting prevention of disease, sanitary living, laws, practices and a healthier environment [20]. That is, ambient air, as an element of the natural environment, is a component that affects the environment and thus human life and health. Ambient (outdoor) air pollution alone kills around 3 million people each year, mainly from noncommunicable diseases. Air pollution continues to rise at an alarming rate, and affects economies and people's quality of life; it is a public health emergency [21, p. 11]. Proper legal regulation of ambient air quality which is ensured primarily by its protection is a significant element of the designated area.

\section{THE AIM}

To examine the legal and regulatory basis for ambient air protection as an essential element of the environment that affects the health of the population and the biological security system in general.

\section{MATERIALS AND METHODS}

Under the link Air quality in Europe - 2020 report [22, p. $15]$ among the acts and policies that are crucial for the regulation of this particular area there are Directive 2008/50/EC of the European Parliament and of the Council of 21 May 2008 on ambient air quality and cleaner air for Europe (hereinafter - Directive 2008/50/EC), Directive 2004/107/ EC of the European Parliament and of the Council of 15 December 2004 relating to arsenic, cadmium, mercury, nickel and polycyclic aromatic hydrocarbons in ambient air (hereinafter - Directive 2004/107/EC) [23], Commission Implementing Decision of 12 December 2011 laying down rules for Directives 2004/107/EC and 2008/50/EC of the European Parliament and of the Council as regards the reciprocal exchange of information and reporting on ambient air quality (notified under document $\mathrm{C}(2011)$ 9068) [24], etc. The provisions of each of these directives are aimed at maintaining the quality of ambient air and are reflected through the implementation of appropriate measures.

Particularly, under the second preambular paragraph in Directive 2008/50/EC: in order to protect human health and the environment as a whole, it is particularly important to combat emissions of pollutants at source and to identify and implement the most effective emission reduction measures at local, national and Community level. Therefore, emissions of harmful air pollutants should be avoided, prevented, or reduced and appropriate objectives set for ambient air quality taking into account relevant World Health Organisation standards, guidelines, and programs. That is, the main task, defined in the process of ensuring the proper quality of the ambient air, is to reduce the emissions of air pollutants, while meeting certain requirements. Namely, Art. 1 Directive 2008/50 / EC specifies the measures that are conditioned by the need to ensure ambient air quality, using appropriate criteria, when operating certain information with proper access to it, to achieve the most effective result in their implementation.

Regarding Directive 2004/107/EC, it states that according to scientific evidence arsenic, cadmium, nickel, and some polycyclic aromatic hydrocarbons are human genotoxic carcinogens and that there is no identifiable threshold below which these substances do not pose a risk to human health (the third preambular paragraph). Mercury is a very hazardous substance for human health and the environment. It is present throughout the environment and, in the form of methylmercury, can accumulate in organisms, and in particular to concentrate in organisms higher up the food chain. Mercury released into the atmosphere is capable of being transported over long distances (para. 9 of the preamble). In its turn, preambular paragraph 11 of that Directive states that the effects of arsenic, cadmium, mercury, nickel, and polycyclic aromatic hydrocarbons on human health, including via the food chain, and the environment as a whole, occur through concentrations in ambient air and via deposition; the accumulation of these substances in soils and the protection of ground water should be taken into account. That is while analyzing the above-mentioned provisions we conclude that the substances listed above are dangerous to human health. This risk is reinforced by the fact that they are able to concentrate and move in the air. Taking this into account, Art. 1 Directive 2004/107/EC defines among its tasks those aimed at avoiding, preventing, or reducing harmful effects of said pollutants on the environment in general and human health in particular.

Similarly, if we turn to the content of Commission Implementing Decision of 12 December 2011 laying down rules for Directives 2004/107/EC and 2008/50/EC of the European Parliament and of the Council as regards the reciprocal exchange of information and reporting on ambient air quality (notified under document C(2011) 9068), then according to its article 1, this Decision establishes rules implementing Directives 2004/107/EC and 2008/50/EC as regards: (a) Member States obligations to report on the assessment and management of ambient air quality; (b) Member States reciprocal exchange of information concerning networks and stations, and the measurements of air quality obtained from those stations that are selected by Member States for the purpose of reciprocal exchange from amongst existing stations. Accordingly, it reiterates the need for certain entities to report on the quality of the ambient air and to cooperate with each other towards the mutual exchange of information regarding the outlined area.

That is, legal regulation of ambient air protection is important in the implementation of various measures aimed at preserving its quality and, accordingly, preventing possible adverse effects on human health. Hence, protection of ambient air refers to environmental protection activity involving the construction, maintenance, and operation of facilities for the reduction of emissions into ambient air, or of concentrations in the air, of air pollutants through the use 


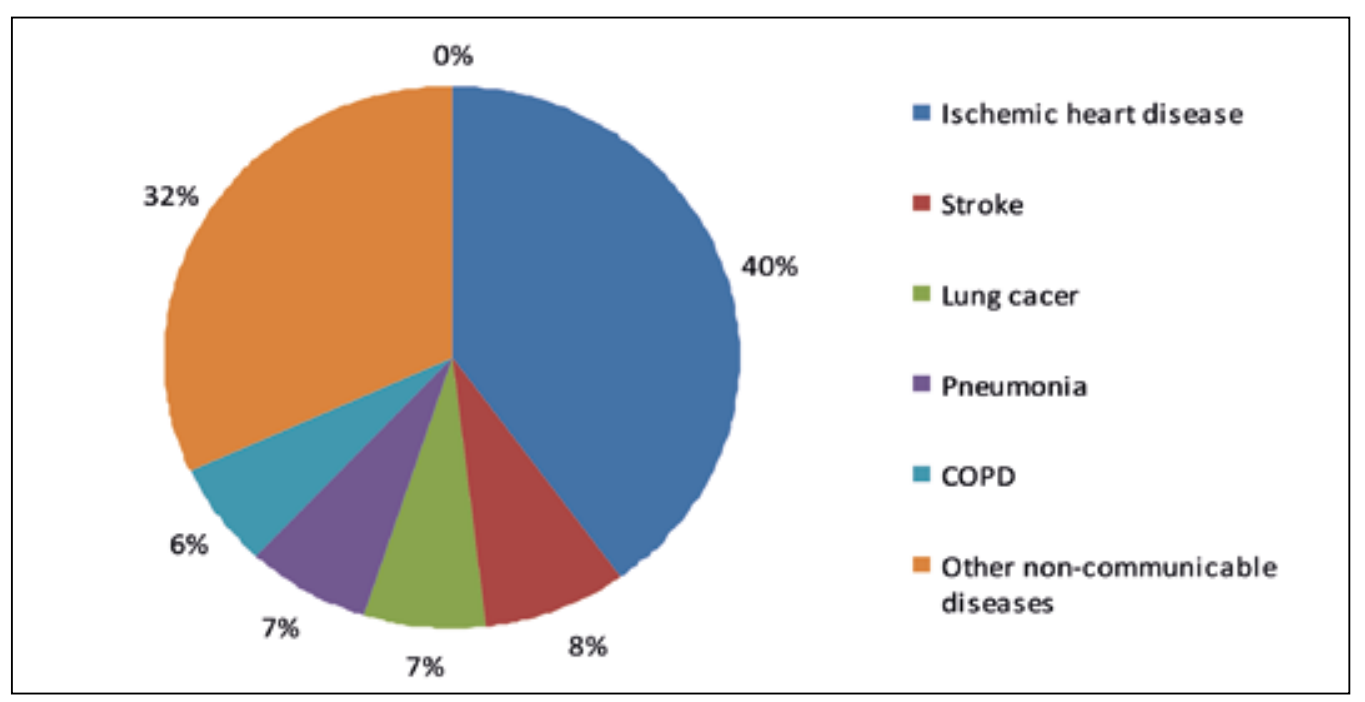

Fig. 1. Estimated excess mortality attributed to air pollution in Europe, and the contributing disease categories. of particulate emission collectors, gaseous emission control devices or other technical means [25]. Thus, ambient air protection is a certain activity that deals with reducing the number of emitted pollutants that get into the air by monitoring the establishment of polluting facilities, as well as the use of waste treatment facilities in carrying out such activities. However, it should be noted that protection measures are not limited to such activities, as the negative effects on the ambient air may have different origins. This can be asserted by referring to the differentiation of pollution sources. In particular, air pollutants may be categorized as primary or secondary. Primary pollutants are directly emitted to the atmosphere, whereas secondary pollutants are formed in the atmosphere from precursor pollutants through chemical reactions and microphysical processes. Air pollutants may have a natural, anthropogenic or mixed origin, depending on their sources or the sources of their precursors [22, p. 30]. Air pollutants are emitted from natural sources (such as volcanoes, vegetation, soils, and oceans) as well as from human activity-related sources, also known as 'anthropogenic' sources (from a variety of sectors across the economy). Particulate matter is emitted mainly by heating, industry, and transport; nitrogen oxides are mainly released by the transport sector; the bulk of sulfur oxides emissions come from energy production and non-road transport; almost all ammonia emissions come from agriculture; volatile organic compounds are mainly emitted from paints and chemicals used in manufacture and maintenance; carbon monoxide emissions come from heating and transport; and most methane emissions come from the agriculture, waste and energy sectors [26, p. I]. The release of harmful substances into ambient air has a negative impact on public health and may be a direct or indirect prerequisite for death. For example, one study claims that there are 790,000 excess deaths per year in Europe due to ambient air pollution (figure 1) [27].

\section{REVIEW AND DISCUSSION}

Given the above, we would like to mention that in the context of sources for substances with adverse effects on the ambient air we can also talk about the classification of measures directed to prevent or eliminate their occurrence. In its turn, they will depend on the very nature of such a source and the negative impact it can have, in particular, for example, volcanoes. Volcanic eruptions produce hazardous effects on the environment, climate, and the health of the exposed persons, and are associated with the deterioration of social and economic conditions. Along with magma and steam $(\mathrm{H} 2 \mathrm{O})$, the following gases surface in the environment: carbon dioxide (CO2) and sulfur dioxide (SO2), carbon monoxide (CO), hydrogen sulfide (H2S), carbon sulfide (CS), carbon disulfide (CS2), hydrogen chloride $(\mathrm{HCl})$, hydrogen $(\mathrm{H} 2)$, methane (CH4), hydrogen fluoride (HF), hydrogen bromide $(\mathrm{HBr})$ and various organic compounds, as well as heavy metals (mercury, lead, gold). During volcanic eruptions and their immediate aftermath, increased respiratory system morbidity has been observed as well as mortality among those affected by volcanic eruptions. Unfavorable health effects could partly be prevented by the timely application of safety measures [28]. In cases like these, the preventative measures are the ones that allow to identify these processes in time and to protect people as much as possible before their onset, during, or when their consequences are eliminated. Those consequences can have negative effects on public health and the environment. Moreover, important decisions need to be taken by governments to reduce air pollution and its hazardous effects on health and the environment. New studies on the long-term effects of low doses of air pollutants are needed, including important partnerships between epidemiologists, toxicologists, metrologists, chemists, physicists, and biologists [1, p. 118].

With regards to the sources that have an anthropogenic genesis, in addition to scientific research, which is of primary importance in preventing potential negative effects in the context of air pollution from natural sources, the legal regulation of various activities is essential. Such activities may cause the release of substances into the air, which might be a threat to human health and the environment. Legal regulation is a key element of the policy used by the EU and its Member States to achieve the relevant objectives [29, p. 7]. 
Such acts that determine the guidelines for activity and regulate the outlined area, in addition to those already mentioned above, include Communication from the Commission to the European Parliament, the Council, the European Economic, and Social Committee, and the Committee of the Regions a Clean Air Programme for Europe [30], The European Green Deal [31], EU Action Plan: 'Towards Zero Pollution for Air, Water and Soil' [32], etc. Furthermore, the relevant legal regulations are also present in the legislation of the European Union member States. For instance, Ambient Air Protection Act, Law on clean air [33], Decree on ambient air quality [34], Regulation on levels of certain substances in ambient air [35], etc.

In addition to legal regulation of the proper air quality, there are court cases, which contribute strongly to ensuring and improving such conservation activities. Those court cases draw attention to matters of particular importance and the need to address them in general or to change how they are implemented. Even though the European Convention on Human Rights does not enshrine any right to a healthy environment as such, the European Court of Human Rights has been called upon to develop its case-law in environmental matters since the exercise of certain Convention rights may be undermined by the existence of harm to the environment and exposure to environmental risks [36, p. 1].

In particular, for example, the case Cordella and Others v. Italy (European Court of Human Rights) concerning ongoing air pollution by steelworks, operating since 1965 in Taranto. The plaintiffs were several dozen individuals living in the more or less immediate vicinity of the steelworks. They complained about the lack of action from the State to avert the effects of the factory's toxic emissions on their health. As a conclusion, among other things, it was stated that the environmental plan approved by the national authorities, setting out the necessary measures and actions to secure environmental and health protection to the population, was, therefore, to be implemented as rapidly as possible. The Court also held, unanimously, that there had been a violation of Article 13 taken in conjunction with Article 8 of the Convention [37]. Thus, the plaintiffs, when conveying their legal arguments in court, emphasized the lack of appropriate measures from the state in preventing negative impact on their health from hazardous substances.

The case Guerra and Others v. Italy - this case dealt with the failure to provide the local population with information about risk factors and how to proceed in event of an accident at a nearby chemical factory. The claimants all lived in the town of Manfredonia. Approximately one kilometer away was the Enichem agricoltura company's chemical factory. The applicants claimed that in the course of its production cycle the factory released large quantities of inflammable gas a process which could have led to explosive chemical reactions, releasing highly toxic substances and other dangerous substances. Severe environmental pollution could affect the individuals' well-being and prevent them from enjoying their homes in such a way as to affect their private and family life adversely. The court concluded that the responsible party had not fulfilled its obligation to secure the claimants' right to respect for their private and family life [38]. Accordingly, the court ruled that significant environmental pollution could be an obstacle to the proper functioning of the people and make it impossible to fully exercise their right to respect for their private and family life.

Additionally, in the case Tătar v. Romania the claimants, father, and son, alleged in particular that the technological process (involving the use of sodium cyanide in the open air) used by a company in their gold mining activity put their lives in danger. Part of the company's activity was located in the vicinity of the claimants' home. In January 2000 an environmental accident had occurred at the site. A United Nations study reported that a dam had breached, releasing about $100,000 \mathrm{~m} 3$ of cyanide-contaminated tailings water into the environment. The Court поряд 3 іншим held that there had been a violation of Article 8 of the Convention, finding that the Romanian authorities had failed in their duty to assess, to a satisfactory degree, the risks that the activity of the company operating the mine might entail, and to take suitable measures in order to protect the rights of those concerned to respect for their private lives and homes, and more generally their right to enjoy a healthy and protected environment. In this case, the Court recalled in particular that pollution could interfere with a person's private and family life by harming his or her well-being and that the State had a duty to ensure the protection of its citizens by regulating the authorizing, setting-up, operating, safety and monitoring of industrial activities, especially activities that were dangerous for the environment and human health [39, p. 14]. Thus, as in the previous case, the court indicates the lack of possibility for people to properly exercise their right to enjoy a healthy and protected environment if no measures to prevent harm to the environment are implemented.

Accordingly, the protection of the environment in general and the ambient air, in particular, is based on ensuring its quality in various ways so that it does not have a negative impact on human health, life and the biological security system. Air pollution is a global threat leading to large impacts on human health and ecosystems. Emissions and concentrations have increased in many areas worldwide. In Europe, air quality remains poor in many areas, despite reductions in emissions and ambient concentrations [22, p. 9]. Air pollutants can cause serious health problems, including respiratory problems (asthma, irritation of the lungs, bronchitis, pneumonia, decreased resistance to respiratory infections), allergies, adverse neurological, reproductive, and developmental effects, cancer, and even early death [1, p. 117].

\section{CONCLUSIONS}

Therefore, given the above, we can conclude that the air is an integral part of the natural environment whose proper condition both directly and indirectly affects human health and life, the biological security system in general. Ambient air protection in the biological security system is a set of certain 
activities directed at reducing the number of pollutants that get into the air by one means or another. Such activities are carried out by implementing appropriate measures, which are conditioned by the source of the substance, which may pose a threat to public health when released into the atmosphere. Important elements in the process of environmental protection in general and ambient air, in particular, are the legal basis and case law, which are aimed at minimizing potentially hazardous situations that could endanger human health and life, and in case of such situations to identify the causes and proper way to react to them.

\section{REFERENCES}

1. Pénard-Morand C., Annesi-Maesano I. Air pollution: from sources of emissions to health effects. Breathe 2004 1: 108-119. Available at: https://breathe.ersjournals.com/content/1/2/108

2. Adel Ghorani-Azam, Bamdad Riahi-Zanjani, and Mahdi Balali-Mood Effects of air pollution on human health and practical measures for prevention in Iran. Available at: https://www.ncbi.nlm.nih.gov/pmc/ articles/PMC5122104/

3. Wanner HUEffects of atmospheric pollution on human health. Available at: https://pubmed.ncbi.nlm.nih.gov/8405297/

4. Pashkov V., Trotska M. Natural environment as component of public health: some aspects of its legal regulation. Wiad Lek. 2019;2:261-267.

5. Vitalii M. Pashkov, Maryna V. Trotska, Oleksii S. Soloviov Right to child health in context of natural environmental security. Wiad Lek. 2019;3:418-425.

6. Antonina H. Bobkova, Maryna V. Trotska Safe Natural Environment as Guarantee of Exercising the Right to Health. Wiad Lek. 2019;8:15711576.

7. Oleksii S. Soloviov, Maryna V. Trotska, Bogdan V. Derevyanko Legal regulation of the proper natural environmental conditions as an integral environmental health component. Wiad Lek. 2020;9:2091-2097.

8. Vitalii M. Pashkov, Maryna V. Trotska, Andrii 0. Harkusha The theoretical and legal basis for environmental risk as a possible measurement of harm to the environment and human health. Wiad Lek 2020; 11:25232527.

9. Vitalii Pashkov, Olena Batyhina, Liudmyla Leiba Ensuring right to organic food in public health system. Wiad Lek. 2018;1:226-229.

10. Olena M. Batyhina, Bogdan V. Derevyanko, Vitalii V. Kadala. Recreational lands as a component of health care: some aspects of legal regulation. Wiad Lek. 2020;12: 2860-2864.

11. Vystavna Y., Cherkashyna M., van der Valk M.R., 2018. Water laws of Georgia, Moldova and Ukraine: current problems and integration with the EU legislation. Water International (IF2016=1.538, IF5yr=1.4; Q2). doi: $10.1080 / 02508060.2018 .1447897$.

12. Alla K. Sokolova, Tetyana B. Vilchyk, Maryna K. Cherkashyna. Ensuring the environmental rights as a prerequisite for the rights to health in Ukraine and the European Union. Wiad Lek. 2019;12:2489-2495. doi: 10.36740/WLek201912216

13. Sokolova A, Cherkashyna M'The Legal Regulation of the Use of Natural Healing Resources: The Theory and Practice of Disputes Resolution'. Access to Justice in Eastern Europe. 2021;2(10):144-163. doi: 10.33327/ AJEE-18- 4.2-n000065

14. Air/Glossary European Environment Agency. Available at: https://www. eea.europa.eu/help/glossary/gemet-environmental-thesaurus/air

15. Air / National Geographic Resource library. Available at: https://www. nationalgeographic.org/encyclopedia/air
16. Ambient air / Glossary European Environment Agency. Available at: https://www.eea.europa.eu/themes/air/air-quality/resources/ glossary/ambient-air

17. Ambient air / Glossary of Terms. Available at: http://www.vale.com/ canada/EN/aboutvale/communities/sudbury/sudbury-environment/ environmental-reporting-sudbury/air-quality-monitoring-results/ Documents/Particulate-Monitoring-Program-Glossary-of-Terms.pdf

18. Directive 2008/50/EC of the European Parliament and of the Council of 21 May 2008 on ambient air quality and cleaner air for Europe. Available at: https://eur-lex.europa.eu/legal-content/EN/ TXT/?uri=CELEX\%3A32008L0050

19. Atmospheric Air Protection Act 2016 (2019) Estonia. Available at: http:// www.fao.org/faolex/results/details/ru/c/LEX-FAOC178394

20. Public health / Glossary European Environment Agency. Available at: https://www.eea.europa.eu/help/glossary/gemet-environmentalthesaurus/public-health

21. Ambient Air Pollution: A global assessment of exposure and burden of disease, World Health Organization, 2016. Available at: https://apps. who.int/iris/handle/10665/250141

22. Air quality in Europe - 2020, Report 9/20, European Environment Agency, 2020 (EEA, 2020). Available at: https://www.eea.europa.eu/ publications/air-quality-in-europe-2020-report

23. Directive 2004/107/EC of the European Parliament and of the Council of 15 December 2004 relating to arsenic, cadmium, mercury, nickel, and polycyclic aromatic hydrocarbons in ambient air. Available at: https://eur-lex.europa.eu/legal-content/EN/ TXT/?uri=CELEX\%3A32004L0107

24. Commission Implementing Decision of 12 December 2011 laying down rules for Directives 2004/107/EC and 2008/50/EC of the European Parliament and of the Council as regards the reciprocal exchange of information and reporting on ambient air quality (notified under document C(2011) 9068). Available at: https://eur-lex.europa.eu/ legal-content/en/TXT/?uri=CELEX:32011D0850

25. Protection of ambient air / Glossary of statistical terms. Available at: https://stats.oecd.org/glossary/detail.asp?ID=2181

26. Bourguignon D., Air quality - pollution sources and impacts, EU legislation and international agreements, Study, European Parliamentary Research Service, European Parliament, 2018. Available at: https://www.europarl.europa.eu/thinktank/en/document. $\mathrm{html}$ ?reference $=$ EPRS_STU(2018)625114

27. Jos Lelieveld, Klaus Klingmüller, Andrea Pozzer, Ulrich Pöschl, Mohammed Fnais, Andreas Daiber, Thomas Münzel Cardiovascular disease burden from ambient air pollution in Europe reassessed using novel hazard ratio functions European Heart Journal. 2019;20:15901596.

28. Eugenija Zuskin, Jadranka Mustajbegović, Jagoda6 Doko Jelinić, Jasna Pucarin-Cvetković, Milan Milosević Effects of volcanic eruptions on environment and health. Available at: https://pubmed.ncbi.nlm.nih. gov/18063533/

29. EU policy on air quality: implementation of selected EU legislation, European Parliamentary Research Service, 2021 (EPRS, 2021). Available at: https://www.europarl.europa.eu/thinktank/en/document. $\mathrm{html}$ ? reference=EPRS_STU(2021)654216

30. Communication from the Commission to the Council, the European Parliament, the European Economic, and Social Committee, and the Committee of the Regions - «A Clean Air Programme for Europe», (2013) final. Available at: https://eur-lex.europa.eu/legal-content/EN/ ALL/?uri=CELEX\%3A52013DC0918 
31. Communication from the Commission to the European Parliament, the European Council, the Council, the European Economic, and Social Committee and the Committee of the Regions The European Green Deal COM/2019/640 final Available at: https://eur-lex.europa.eu/ legal-content/EN/TXT/?uri=COM\%3A2019\%3A640\%3AFIN

32. Communication from the Commission to the European Parliament, the European Council, the Council, the European Economic, and Social Committee and the Committee of the Regions Pathway to a Healthy Planet for All EU Action Plan: 'Towards Zero Pollution for Air, Water, and Soil'COM/2021/400 final. Available at: https://eur-lex.europa.eu/legalcontent/EN/TXT/?uri=CELEX\%3A52021DC0400\&qid=1623311742827

33. Law on clean air 1996 (2012) Bulgaria. Available at: http://www.fao. org/faolex/results/details/ru/c/LEX-FAOC164792

34. Decree on ambient air quality 2011 Slovenia. Available at: http://www. fao.org/faolex/results/details/ru/c/LEX-FAOC114759/

35. Regulation on levels of certain substances in ambient air 2012 Poland. Available at: http://www.fao.org/faolex/results/details/en/c/LEXFAOC129545

36. Environment and the European Convention on Human Rights. April 2021. Available at: https://www.echr.coe.int/documents/fs_environment_ eng.pdf

37. Cordella and Others v. Italy, Jan 24, 2019. Available at: https://laweuro. com $/ ? p=514$

38. Guerra and Others v. Italy, Feb 19, 1998. Available at: https://www. ecolex.org/details/court-decision/case-of-guerra-and-others-v-italya1113ab0-f99e-47d6-8076-1a51e18e353e/

39. Tătar v. Romania, Jan 27,2009. Available at: https://www.echr.coe.int/ documents/fs_environment_eng.pdf

\section{ORCID and contributionship:}

Vitalii M. Pashkov: 0000-0001-9489-7768 ${ }^{A, B, D-F}$

Maryna V. Trotska: 0000-0003-3420-0353 ${ }^{A, B, D-F}$

Liudmyla M. Nikolenko: 0000-0002-3437-6968 A,B,D-F

\section{Conflict of interest:}

The Authors declare no conflict of interest

\section{CORRESPONDING AUTHOR}

\section{Vitalii M. Pashkov}

Poltava Law Institute Of Yaroslav

Mudryi National Law University

Pershotravnevy Avenue, 5, 36011, Poltava, Ukraine

v.pashkov26.06@ukr.net

Received: 29.06 .2021

Accepted: 25.08 .2021

A - Work concept and design, B - Data collection and analysis, C - Responsibility for statistical analysis,

D-Writing the article, $\mathbf{E}$-Critical review, $\mathbf{F}$ - Final approval of the article 